\title{
Pengaruh Jenis Persalinan Bedah Sesar terhadap Kejadian Diare dan ISPA pada Bayi
}

\author{
Nia Fararid Askar¹, Firman F. Wirakusumah², Maringan D.LT. ${ }^{3}$, Hadi Susiarno ${ }^{4}$ \\ Kusnandi Rusmil5, Dwi Agustian 6
${ }^{1}$ Departemen Layanan dan Informasi Kesehatan, Sekolah Vokasi, Universitas Gadjah Mada 2,3,4Departemen Obstetri dan Ginekologi, Fakultas Kedokteran, Universitas Padjadjaran
${ }^{5}$ Departemen Ilmu Kesehatan Anak, Fakultas Kedokteran, Universitas Padjadjaran ${ }^{6}$ Departemen Ilmu Kesehatan Masyarakat, Fakultas Kedokteran, Universitas Padjadjaran fararid1819@gmail.com ${ }^{1}$

\section{ABSTRAK \\ Diajukan 25 Mei 2020 Diperbaiki 30 November 2020 Diterima 4 Desember 2020}

Latar Belakang: Persalinan bedah sesar mempunyai risiko kegagalan pemberian ASI pada bayi karena durasi Inisiasi Menyusu Dini yang lebih singkat dan mobilisasi dini yang lebih lama daripada persalinan normal sehingga dapat mengakibatkan bayi rentan terhadap diare dan ISPA.

Tujuan: Menganalisis pengaruh jenis persalinan bedah sesar dibandingkan dengan persalinan normal terhadap kejadian diare dan ISPA berdasarkan faktor: lama pemberian ASI Eksklusif, Inisiasi Menyusu Dini, mobilisasi dini, dan status imunisasi.

Metode: Rancangan penelitian yang digunakan adalah studi kasus-kontrol. Sebanyak 220 responden (110 responden pada kejadian diare dan 110 responden pada kejadian ISPA) didapat berdasarkan rumus studi analitik komparatif tidak berpasangan dengan teknik pengambilan sampel consecutive sampling. Analisis data menggunakan uji regresi logistik.

Hasil: Uji regresi logistik pada ibu dengan persalinan bedah sesar terhadap kejadian diare pada bayi nilai $\mathrm{OR}=0,178(0,065-0,486)$, Ibu dengan persalinan bedah sesar terhadap kejadian ISPA pada bayi mempunyai nilai $\mathrm{OR}=2,773(1,058-7,269)$.

Kesimpulan: Persalinan bedah sesar dapat melindungi terhadap kejadian diare dan persalinan bedah sesar berisiko terhadap kejadian ISPA. Pemberian ASI Eksklusif dapat mencegah bayi dan balita dari kejadian diare dan ISPA.

Kata Kunci: ASI Eksklusif; Diare; Infeksi Saluran Pernapasan Akut; Persalinan Bedah Sesar; Persalinan Normal

\section{ABSTRACT}

Background: Cesarean delivery has a risk of failure to breastfeed the baby because the duration of early breastfeeding is shorter and early mobilization is longer than normal delivery so that it can make the baby exposed to diarrhea and ARI.

Objective: To analyze the effect of type of cesarean delivery compared to normal delivery on the incidence of diarrhea and ARI based on factors: duration of exclusive breastfeeding, early initiation of breastfeeding, early mobilization, and immunization status.

Method: The research design used was a case-control study. A total of 220 respondents (110 respondents for diarrhea and 110 respondents for ARI) were obtained based on the unpaired comparative analytical study formula with a consecutive sampling technique. Data analysis using a logistic regression test.

Results: Logistic regression test in mothers with cesarean delivery on the incidence of diarrhea in infants $O R=$ 0.178 (0.065-0.486), mothers with cesarean delivery on the incidence of ARI in infants had a value of OR= $2.773(1.058-7.269)$.

Conclusion: Cesarean delivery can protect against the incidence of diarrhea and cesarean delivery is at risk for the incidence of ARI. Exclusive breastfeeding can prevent the incident of diarrhea and ARI.

Keywords: Exclusive Breastfeeding; Diarrhea; Acute Respiratory Infection (ARI); Caesarean Section; Normal Delivery 
PENDAHULUAN

Salah satu program Sustainable Developmental Goals (SDGs) yang merupakan pembangungan berkelanjutan dari program Millennium Development Goals (MDGs) menetapkan salah satu tujuannya yaitu untuk tetap berupaya dalam menurunkan angka kesakitan dan kematian bayi. Pada umumnya penyebab kematian pada bayi dan balita disebabkan oleh beberapa penyakit seperti infeksi saluran pencernaan (diare), infeksi saluran pernapasan akut (ISPA), dan malaria. (Anung, 2015).

Menurut World Health Organization (WHO), lebih dari 700.000 bayi dan balita meninggal akibat penyakit diare dan 156 juta bayi dan balita terdiagnosa ISPA serta menyumbangkan dua juta kematian dalam lima tahun terakhir. Persentase kejadian diare di Indonesia sebesar 69,1\% dan persentase di provinsi Jawa Timur sebesar $61,1 \%$. Cakupan penyakit diare di Kota Surabaya ditemukan sebanyak 92.072 kasus $(79,25 \%)$, sedangkan persentase kejadian ISPA di Indonesia sebesar $56,58 \%$ dari seluruh balita dan persentase ISPA di provinsi Jawa Timur mencapai $56,04 \%$, cakupan penyakit ISPA di Kota Surabaya ditemukan sebanyak 22.114 kasus (29,18\%). Tidak diberikannya ASI Eksklusif pada bayi dan pemberian imunisasi yang tidak lengkap merupakan salah satu penyebab tingginya angka kejadian penyakit diare dan ISPA (Badan Pusat Statistik, 2013).

Pemberian ASI Eksklusif dan imunisasi sebagai upaya untuk memberikan kekebalan bayi terhadap penyakit infeksi (Quigley et al., 2016). Imunisasi merupakan proses memberikan zat kekebalan dari luar pada bayi, sedangkan zat kekebalan dari ibu pada bayi diberikan melalui pemberian Air Susu Ibu (ASI) dimana kandungannya dapat membantu imunitas tubuh bayi dalam melawan infeksi virus dan bakteri (Hanieh et al., 2015).

Keberhasilan ibu dalam memberikan
ASI eksklusif juga bergantung pada satu jam pertama setelah bayi lahir melalui proses Inisiasi Menyusu Dini (IMD) (Kaur et al., 2016). Salah satu hambatan pemberian ASI Eksklusif adalah berdasarkan jenis persalinan (Sakalidis et al., 2013). Persalinan bedah sesar mempunyai beberapa risiko pada ibu, seperti durasi Inisiasi Menyusu Dini kurang dari 60 menit dan pengaruh pemberian anestesi pada ibu postpartum dengan operasi bedah sesar dapat membuat mobilisasi dini menjadi lebih lama daripada ibu postpartum secara normal pervaginam sehingga dapat memengaruhi ibu dalam memberikan ASI Eksklusif pada awal kelahiran (Dalal, Bosak \& Berlin, 2014). Adanya beberapa risiko maka dapat menghambat pemberian zat kekebalan baik dari ibu melalui pemberian ASI Eksklusif maupun dari imunisasi sehingga bayi rentan terserang penyakit infeksi seperti diare dan ISPA (UNICEF, 2013).

Berdasarkan hal-hal di atas, peneliti tertarik melakukan penelitian untuk Pengaruh Persalinan Bedah Sesar Dibandingkan dengan Persalinan Normal terhadap Kejadian Diare dan ISPA pada Bayi Berdasarkan Faktor Lama Pemberian ASI Eksklusif, Inisiasi Menyusu Dini (IMD), Mobilisasi Dini, dan Status Imunisasi.

\section{METODE}

Metode penelitian yang digunakan yaitu analitik observasional dengan menggunakan rancangan studi kasuskontrol (case control). Ibu yang memiliki bayi usia $\geq 6$ sampai 12 bulan yang pernah mengalami diare dan ISPA dalam waktu 14 hari terakhir selama penelitian (kelompok kasus) dan yang tidak pernah mengalami diare dan ISPA dalam waktu 14 hari terakhir selama penelitian (kelompok kontrol) merupakan sampel pada penelitian ini. Besar sampel penelitian ini dihitung menggunakan rumus studi analitik komparatif dua 
Pengaruh Jenis Persalinan Bedah Sesar terhadap Kejadian Diare...

kelompok tidak berpasangan dan jumlah sampel yang digunakan berjumlah 220 responden dengan rincian 110 responden untuk kejadian diare dan 110 responden (55 responden pada setiap kelompok kasus dan kontrol). Teknik pengambilan sampel menggunakan consecutive sampling yaitu pengambilan sampel diambil sampai jumlah sampel terpenuhi berdasarkan kriteria inklusi dan eksklusi.

Pada penelitian ini, responden diberikan informed consent lalu mengisi kuesioner tentang riwayat persalinan ibu, lama pemberian ASI pada bayi, Inisiasi Menyusu Dini, Mobilisasi Dini, dan status imunisasi. Analisis data menggunakan uji regresi logistik. Penelitian ini juga telah mendapatkan persetujuan etik dari Komisi Etik Penelitian Kesehatan Fakultas Kedokteran Universitas Padjadjaran dengan No. 68/ UN6.C.10/PN/2017 pada tanggal $10 \mathrm{Juli}$ 2017.

\section{HASIL DAN PEMBAHASAN}

\section{A. Karakteristik Subjek Penelitian}

Tabel 1. Distribusi Frekuensi Karakteristik Responden Berdasarkan Kejadian Diare pada Bayi

\begin{tabular}{|c|c|c|c|c|}
\hline \multirow[b]{2}{*}{ No. } & \multirow[b]{2}{*}{ Karakteristik } & \multicolumn{2}{|c|}{ Diare } & \multirow[b]{2}{*}{ Nilai-p } \\
\hline & & $\begin{array}{l}\text { Kasus } \\
(\mathrm{n}=55)\end{array}$ & $\begin{array}{c}\text { Kontrol } \\
(n=55)\end{array}$ & \\
\hline \multirow[t]{4}{*}{1.} & Usia Ibu & & & \multirow{4}{*}{$0,587^{*}$} \\
\hline & 1. $<20$ tahun & $1(1,8 \%)$ & $1(1,8 \%)$ & \\
\hline & 2. 20 - 34 tahun & $43(78,2 \%)$ & $47(85,5 \%)$ & \\
\hline & 3. $\geq 35$ tahun & $11(20 \%)$ & 7 (12,7\%) & \\
\hline \multirow[t]{3}{*}{2.} & Paritas & & & \multirow{3}{*}{$0,550^{*}$} \\
\hline & 1. Primipara & $21(38,2 \%)$ & $18(32,7 \%)$ & \\
\hline & 2. Multipara & $34(61,8 \%)$ & $37(67,3 \%)$ & \\
\hline \multirow[t]{4}{*}{3.} & Pendidikan & & & \multirow{4}{*}{$0,057^{*}$} \\
\hline & 1. SD & $3(5,5 \%)$ & $0(0 \%)$ & \\
\hline & 2. SMP\&SMA & $29(52,7 \%)$ & $22(40 \%)$ & \\
\hline & 3. PT & $23(41,8 \%)$ & $33(60 \%)$ & \\
\hline \multirow[t]{3}{*}{4.} & Pekerjaan & & & \multirow{3}{*}{$0,035^{*}$} \\
\hline & 1. Tidak Bekerja & $24(43,6 \%)$ & $35(63,6 \%)$ & \\
\hline & 2. Bekerja & $31(56,4 \%)$ & $20(36,4 \%)$ & \\
\hline
\end{tabular}

Tabel 1 menunjukkan bahwa pada karakteristik usia ibu, baik kelompok kasus maupun kontrol sebagian besar ibu memiliki usia 20 - 34 tahun. Karakteristik paritas pada kelompok kasus maupun kontrol sebagian besar adalah multipara. Karakteristik pendidikan pada kelompok kasus Sebagian besar adalah SMP \& SMA dan pendidikan kelompok kontrol sebagian besar adalah Perguruan Tinggi (PT). Karakteristik pekerjaan pada kelompok kasus sebagian besar adalah bekerja dan pada kelompok kontrol sebagian besar tidak bekerja. Kesimpulan dari tabel 1 didapatkan hasil bahwa pada karakteristik usia ibu, paritas, dan pendidikan mempunyai nilai $\mathrm{p}>0,05$, sedangkan pada karakteristik pekerjaan mempunyai nilai $\mathrm{p}<0,05$.

Tabel 2. Distribusi Frekuensi Karakteristik Responden Berdasarkan Kejadian ISPA pada Bayi

\begin{tabular}{|c|c|c|c|c|}
\hline \multirow[b]{2}{*}{ No. } & \multirow[b]{2}{*}{ Karakteristik } & \multicolumn{2}{|c|}{ ISPA } & \multirow[b]{2}{*}{ Nilai-p } \\
\hline & & $\begin{array}{l}\text { Kasus } \\
(n=55)\end{array}$ & $\begin{array}{c}\text { Kontrol } \\
(n=55)\end{array}$ & \\
\hline \multirow[t]{4}{*}{1.} & Usia Ibu & & & \multirow{4}{*}{$0,225^{*}$} \\
\hline & 1. $<20$ tahun & $3(5,5 \%)$ & $1(1,8 \%)$ & \\
\hline & 2. 20 - 34 tahun & $45(81,8 \%)$ & $41(74,5 \%)$ & \\
\hline & 3. $\geq 35$ tahun & $7(12,7 \%)$ & $13(23,6 \%)$ & \\
\hline \multirow[t]{3}{*}{2.} & Paritas & & & \multirow{3}{*}{$0,047^{*}$} \\
\hline & 1. Primipara & $25(45,5 \%)$ & $15(27,3 \%)$ & \\
\hline & 2. Multipara & $30(54,5 \%)$ & $40(72,7 \%)$ & \\
\hline \multirow[t]{4}{*}{3.} & Pendidikan & & & \multirow{4}{*}{$0,981^{*}$} \\
\hline & 1. SD & $2(3,6 \%)$ & $2(3,6 \%)$ & \\
\hline & 2. SMP\&SMA & $25(45,5 \%)$ & $24(43,6 \%)$ & \\
\hline & 3. PT & $28(50,9 \%)$ & $29(52,7 \%)$ & \\
\hline \multirow[t]{3}{*}{4.} & Pekerjaan & & & \multirow{3}{*}{$0,127^{*}$} \\
\hline & 1. Tidak Bekerja & $24(43,6 \%)$ & $32(58,2 \%)$ & \\
\hline & 2. Bekerja & $31(56,4 \%)$ & $23(41,8 \%)$ & \\
\hline
\end{tabular}

Dari tabel 2 menunjukkan bahwa pada karakteristik usia ibu, baik kelompok kasus maupun kontrol sebagian besar ibu memiliki usia 20 - 34 tahun. Karakteristik paritas pada kelompok kasus maupun kontrol sebagian besar adalah multipara. Karakteristik pendidikan baik pada kelompok kasus maupun kelompok kontrol sebagian besar adalah Perguruan Tinggi (PT). Karakteristik pekerjaan pada kelompok kasus sebagian besar adalah bekerja dan pada kelompok kontrol sebagian besar tidak bekerja. Kesimpulan dari tabel 2 didapatkan hasil bahwa pada karakteristik usia ibu, pendidikan, dan pekerjaan mempunyai nilai $\mathrm{p}>0,05$, sedangkan pada karakteristik paritas mempunyai nilai $\mathrm{p}<0,05$. 
Pengaruh Jenis Persalinan Bedah Sesar terhadap Kejadian Diare...

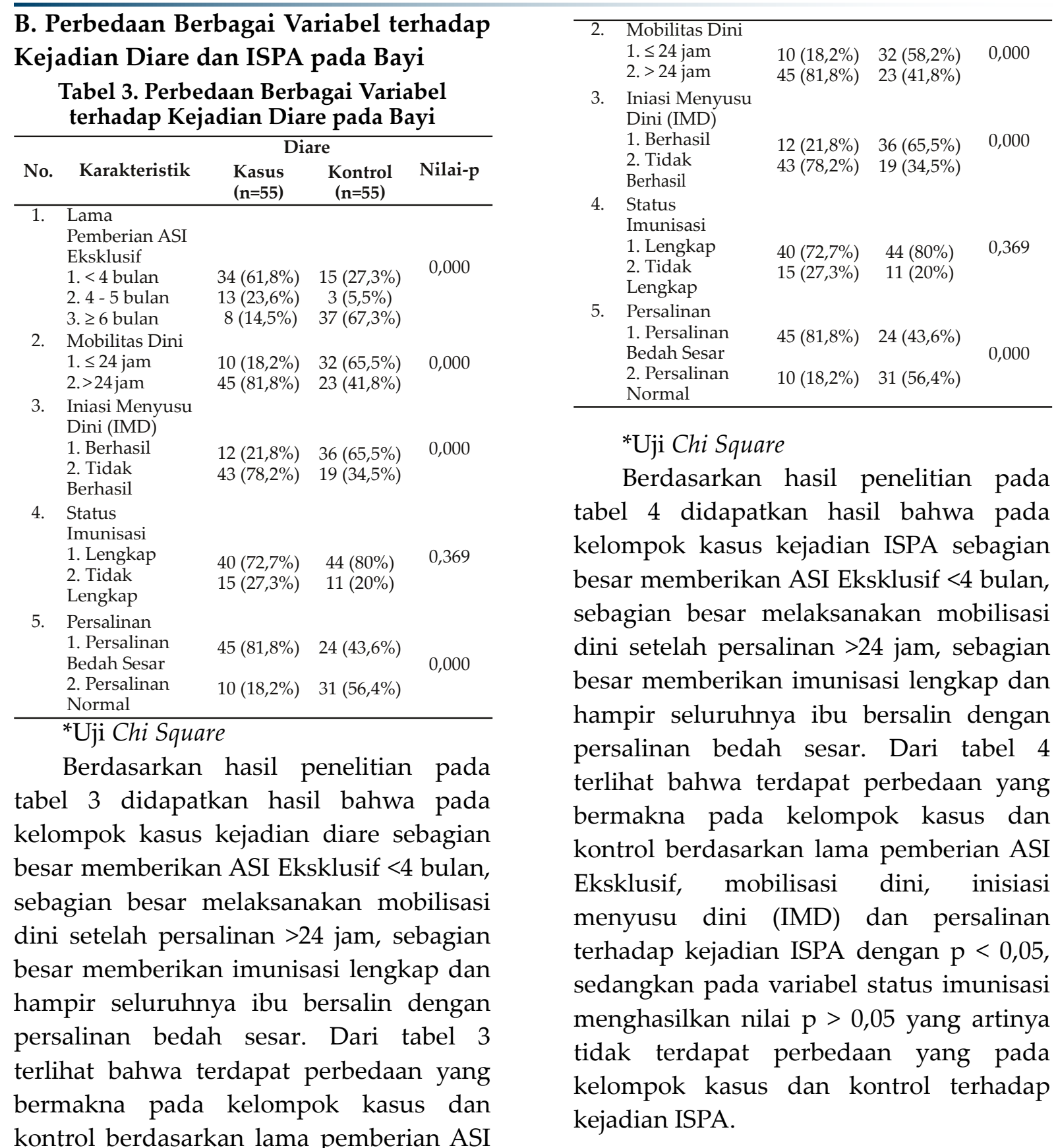

Eksklusif, mobilisasi dini, inisiasi menyusu dini (IMD) dan persalinan terhadap kejadian diare dengan $p<0,05$, sedangkan pada variabel status imunisasi menghasilkan nilai $\mathrm{p}>0,05$ yang artinya tidak terdapat perbedaan yang pada kelompok kasus dan kontrol terhadap kejadian diare.

Tabel 4. Perbedaan Berbagai Variabel terhadap Kejadian ISPA pada Bayi

\begin{tabular}{|c|c|c|c|c|}
\hline \multirow[b]{2}{*}{ No. } & \multirow[b]{2}{*}{ Karakteristik } & \multicolumn{2}{|c|}{ Diare } & \multirow[b]{2}{*}{ Nilai-p } \\
\hline & & $\begin{array}{l}\text { Kasus } \\
(n=55)\end{array}$ & $\begin{array}{c}\text { Kontrol } \\
(n=55)\end{array}$ & \\
\hline 1. & $\begin{array}{l}\text { Lama } \\
\text { Pemberian ASI } \\
\text { Eksklusif } \\
1 .<4 \text { bulan } \\
2.4-5 \text { bulan } \\
3 . \geq 6 \text { bulan }\end{array}$ & $\begin{array}{c}34(61,8 \%) \\
13(23,6 \%) \\
8(14,5 \%)\end{array}$ & $\begin{array}{c}15(27,3 \%) \\
3(5,5 \%) \\
37(67,3 \%)\end{array}$ & 0,000 \\
\hline
\end{tabular}


Pengaruh Jenis Persalinan Bedah Sesar terhadap Kejadian Diare...

C. Pengaruh Berbagai Variabel terhadap Kejadian Diare dan ISPA

Tabel 5. Pengaruh Berbagai Variabel terhadap Kejadian Diare pada Bayi

\begin{tabular}{|c|c|c|c|c|c|}
\hline No. & Variabel & Koefisien B & SE (B) & Nilai-p & OR Adjusted IK (95\%) \\
\hline \multirow[t]{4}{*}{1.} & Lama Pemberian ASI Eksklusif & & & & \\
\hline & 1. $<4$ bulan & 3,092 & 0,807 & 0,000 & $22,023(4,531-107,057)$ \\
\hline & 2. $4-5$ bulan & 1,962 & 0,531 & 0,000 & $7,116(2,514-20,139)$ \\
\hline & 3. $\geq 6$ bulan & - & - & 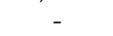 & Ref \\
\hline \multirow[t]{3}{*}{2.} & Mobilisasi Dini & & & & \\
\hline & 1. $\leq 24$ jam & _ & _ & ـ & Ref \\
\hline & 2. $>24$ jam & 0,333 & 1,427 & 0,815 & $1,396(0,085-22,868)$ \\
\hline \multirow[t]{3}{*}{3.} & Inisiasi Menyusu Dini (IMD) & & & & \\
\hline & 1. Berhasil & - & - & - & Ref \\
\hline & 2. Tidak Berhasil & 0,192 & 0,656 & 0,770 & $1,212(0,335-4,381)$ \\
\hline \multirow[t]{2}{*}{4.} & Persalinan & & & & \\
\hline & $\begin{array}{l}\text { 1. Bedah Sesar } \\
\text { 2. Normal }\end{array}$ & $-1,725$ & 0,512 & 0,001 & $\begin{array}{c}0,178(0,065-0,486) \\
\text { Ref }\end{array}$ \\
\hline \multirow[t]{3}{*}{5.} & Pekerjaan & & & & \\
\hline & 1. Tidak Bekerja & ـ & _ & - & Ref \\
\hline & 2. Bekerja & 0,239 & 0,514 & 0,642 & $1,270(0,464-3,476)$ \\
\hline
\end{tabular}

Berdasarkan hasil penelitian pada tabel 5 menunjukkan bahwa pemberian ASI Eksklusif $<6$ bulan memiliki 22 kali risiko terhadap kejadian diare dengan nilai $\mathrm{p}<0,05$. Pelaksanaan mobilisasi $>24$ jam memiliki risiko 1,396 kali terhadap kejadian diare dan tidak memiliki pengaruh terhadap kejadian diare pada bayi dengan nilai $p>0,05$. Keberhasilan pelaksanaan Inisiasi Menyusu Dini kejadian diare dan tidak memiliki pengaruh terhadap kejadian diare pada bayi dengan nilai $p>0,05$. Ibu yang bekerja memiliki risiko 1,270 kali terhadap kejadian diare dan tidak memiliki pengaruh terhadap kejadian diare dengan nilai $p>0,05$. Persalinan bedah sesar melindungi dan memiliki pengaruh terhadap kejadian diare dengan nilai $\mathrm{p}<0,05$. memiliki risiko 1,212 kali terhadap

Tabel 6. Pengaruh Berbagai Variabel terhadap Kejadian ISPA pada Bayi

\begin{tabular}{|c|c|c|c|c|c|}
\hline No. & Variabel & Koefisien B & SE (B) & Nilai-p & OR Adjusted IK (95\%) \\
\hline \multirow[t]{4}{*}{1.} & Lama Pemberian ASI Eksklusif & & & & \\
\hline & 1. $<4$ bulan & 3,092 & 0,807 & 0,000 & $22,023(4,531-107,057)$ \\
\hline & 2. $4-5$ bulan & 1,962 & 0,531 & 0,000 & $7,116(2,514-20,139)$ \\
\hline & 3. $\geq 6$ bulan & - & - & . & Ref \\
\hline \multirow[t]{3}{*}{2.} & Mobilisasi Dini & & & & \\
\hline & 1. $\leq 24$ jam & - & - & - & Ref \\
\hline & 2. $>24$ jam & 0,333 & 1,427 & 0,815 & $1,396(0,085-22,868)$ \\
\hline \multirow[t]{3}{*}{3.} & Inisiasi Menyusu Dini (IMD) & & & & \\
\hline & 1. Berhasil & - & - & - & Ref \\
\hline & 2. Tidak Berhasil & 0,192 & 0,656 & 0,770 & $1,212(0,335-4,381)$ \\
\hline \multirow[t]{2}{*}{4.} & Persalinan & & & & \\
\hline & $\begin{array}{l}\text { 1. Bedah Sesar } \\
\text { 2. Normal }\end{array}$ & $-1,725$ & 0,512 & 0,001 & $\begin{array}{c}0,178(0,065-0,486) \\
\text { Ref }\end{array}$ \\
\hline \multirow[t]{3}{*}{5.} & Pekerjaan & & & & \\
\hline & 1. Tidak Bekerja & - & - & - & Ref \\
\hline & 2. Bekerja & 0,239 & 0,514 & 0,642 & $1,270(0,464-3,476)$ \\
\hline
\end{tabular}

Berdasarkan hasil penelitian pada tabel 5 bahwa Pemberian ASI Ekskusif $<6$ bulan memiliki 3,555 kali risiko terhadap kejadian ISPA dengan nilai $p<0,05$. Pelaksanaan mobilisasi $>24$ jam tidak memiliki pengaruh terhadap kejadian ISPA pada bayi dengan nilai $p>0,05$. Keberhasilan pelaksanaan Inisiasi Menyusu Dini memiliki risiko 1,235 kali terhadap kejadian ISPA dan tidak memiliki pengaruh terhadap kejadian
ISPA pada bayi dengan nilai $p>0,05$. Ibu primipara memiliki risiko 2,018 kali terhadap kejadian ISPA dan tidak memiliki pengaruh terhadap kejadian ISPA dengan nilai $p>0,05$. Persalinan bedah sesar memiliki risiko 2,773 kali terhadap kejadian ISPA dan memiliki pengaruh terhadap kejadian ISPA dengan nilai $\mathrm{p}<0,05$.

Pada hasil penelitian didapatkan bahwa kejadian diare dan ISPA dialami 
Pengaruh Jenis Persalinan Bedah Sesar terhadap Kejadian Diare...

pada bayi yang tidak mendapatkan ASI Ekskulsif sampai dengan usia enam bulan. ASI Eksklusif dan imunisasi diberikan sebagai upaya untuk memberikan kekebalan bayi terhadap penyakit infeksi (Godhia \& Patel, 2013). Zat kekebalan tubuh yang berasal dari ASI Eksklusif dapat membantu mengatur respon imunitas tubuh melawan infeksi. Berdasarkan hasil penelitian lain, bayi yang diberi ASI Eksklusif dapat mengurangi risiko penyakit seperti infeksi saluran pernapasan (ISPA), infeksi saluran pencernaan (diare), alergi, otitis media akut meningitis, dan infeksi saluran kencing (Hanieh et al., 2015).

Salah satu hambatan dalam pemberian ASI Eksklusif adalah jenis persalinan (Brown et al., 2013). Persalinan bedah sesar mempunyai beberapa risiko pada ibu seperti waktu pemulihan atau mobilisasi dini yang lebih lama dan pelaksanaan Inisiasi Menyusu Dini (IMD) yang lebih singkat dibandingkan dengan persalinan normal (Sakalidis et al., 2013).

Tingginya fenomena persentase persalinan bedah sesar di Indonesia pada saat ini, membuat praktik pemberian ASI Eksklusif pada bayi menjadi terhambat (Suryati, 2013). Pada persalinan bedah sesar, proses IMD dilaksakan lebih singkat dan biasanya kepala bayi diarahkan ke puting ibu supaya bayi dapat menyusu tanpa harus menunggu bayi menemukan puting ibu sendiri (Kling et al., 2016). Selain itu, banyaknya risiko pada persalinan bedah sesar membuat ibu rentan memberikan susu formula pada bayi baru lahir akibat terdapat beberapa ketidaknyamanan yang dirasakan diawal setelah bersalin (Quigley et al., 2016).

Pada penelitian ini, persalinan bedah sesar dapat melindungi bayi terhadap kejadian diare karena bayi yang lahir melalui proses bedah sesar tidak terpapar virus atau bakteri dari jalan lahir ibu, terutama seperti E.Coli yang merupakan salah satu bakteri penyebab diare
(Farthing et al, 2013). Persalinan bedah sesar pada kejadian ISPA memiliki risiko 2,773 kali lebih besar terpapar ISPA dimana salah satu penyebabnya adalah ketika bayi diberikan kesempatan untuk melakukan proses IMD di dada ibu, bayi terpapar virus atau bakteri seperti Klebsiella pneumonia, streptococcus, stafilococcus pneumonia (Quigley et al., 2016).

Hasil penelitian ini juga didapatkan bahwa pada ibu yang bersalin secara bedah sesar sebagian besar pemberian ASI diawal menjadi terganggu. Selain itu juga adanya stress akibat nyeri yang dirasakan setelah tidak adanya efek dari anestesi yang diberikan dengan adanya hambatan itu, ibu dengan persalinan bedah sesar mengeluh produksi ASI nya tidak lancar. Produksi ASI yang tidak diberikan secara maksimal pada bayi menyebabkan ibu rentan memberikan susu formula sebagai alternatif pengganti ASI, dimana zat imunitas yang didapat oleh bayi tidak sebaik ASI, sehingga rentan mengalami diare dan ISPA (Farthing et al, 2013).

Penelitian lain menghasilkan bahwa terjadi peningkatan pemberian susu formula pada bayi baru lahir dengan riwayat persalinan bedah sesar yang terencana ( $\mathrm{p}<0,0001)$ (Kendall-Tackett, Cong \& Hale, 2015). Penelitian Desmawati (2013) menghasilkan bahwa terdapat hubungan antara kecepatan waktu pengeluaran ASI pada ibu pasca bedah sesar dengan posisi menyusui, nyeri seteleh operasi bedah sesar, mobilisasi aktif, rawat gabung, dan intervensi rolling massage dengan hasil $\mathrm{p}=0,000$. Penelitian Wulandari \& Dewanti (2014), menyatakan bahwa pada ibu postpartum dukungan tenaga kesehatan dan rawat gabung saat setelah bersalin adalah faktor yang berhubungan dengan praktik pemberian ASI Eksklusif pada ibu bersalin dengan bedah sesar $(p<0,05)$. Keberhasilan Inisiasi Menyusu Dini (IMD) akan berpengaruh terhadap keberhasilan pemberian ASI Eksklusif sampai 
pemberian pada bulan-bulan berikutnya (Kaur et al., 2016).

Status imunisasi bayi pada penelitian ini didapatkan hasil bahwa tidak ada perbedaan antara bayi yang telah mendapatkan imunisasi lengkap dengan bayi yang belum mendapatkan imunisasi lengkap terhadap kejadian diare dan ISPA pada bayi. Kelengkapan imunisasi pada bayi diharapkan dapat menurunkan angka kejadian penyakit infeksi salah satunya diare dan ISPA (Mulyani et al., 2018). Dalam beberapa penelitian juga menunjukkan bahwa bayi yang mempunyai status imunisasi yang lengkap juga memiliki risiko yang sama terhadap kejadian diare dan ISPA (UNICEF, 2013). Dalam penelitian ini beberapa faktor seperti daya tahan tubuh anak sedang turun, faktor gizi anak yang buruk, dan faktor lingkungan yang kurang bersih dapat menyebabkan bayi dan balita tersebut mengalami diare dan ISPA walaupun telah diberikan imunisasi dasar lengkap.

Pemberian ASI Eksklusif dan memberikan imunisasi pada bayi dapat menurunkan angka kesakitan dan kematian bayi di Indonesia akibat penyakit infeksi seperti diare dan ISPA.

\section{PENUTUP}

\section{A. Kesimpulan}

Persalinan bedah sesar dapat melindungi terhadap kejadian diare dan persalinan bedah sesar berisiko terhadap kejadian ISPA. Pemberian ASI Eksklusif dapat mencegah bayi dan balita dari kejadian diare dan ISPA.

\section{B. Saran}

Penelitian selanjutnya tentang kejadian diare dan ISPA yang dilihat dari jenis persalinan, lama pemberian ASI Eksklusif, Inisiasi Menyusu Dini, Mobilisasi Dini, dan Status Imunisasi hendaknya dilakukan dengan menggunakan rancangan penelitian kohort agar dapat meminimalisasi bias yang terjadi, karena akan semakin banyak faktor lain seperti status gizi yang buruk, status sosial-ekonomi, dan faktor lingkungan yang juga dapat memengaruhi kejadian diare dan ISPA pada bayi.

\section{DAFTAR PUSTAKA}

Anung (2015) 'Kesehatan dalam Kerangka Sustainable Development Goals (SDGs)', Rakorpop Kementerian Kesehatan RI, (97), p. 24. Available at: http://

www.pusat2.litbang.depkes.go.id/

pusat2_v1/wp-content/uploads/ 2015/12/SDGs-Ditjen-BGKIA.pdf.

Badan Pusat Statistik et al. (2013) 'Survei Demografi dan Kesehatan Indonesia 2012', Sdki, p. 16. doi: 10.1111/j.14710528.2007.01580.x.

Brown, C. R. L. et al. (2013) 'Rates And Determinants Of Exclusive Breastfeeding In First 6 Months Among Women In Nova Scotia: A Population-Based Cohort Study', CMAJ Open, 1(1), pp. E9-E17. doi: 10.9778/cmajo.20120011.

Dalal, P. G., Bosak, J. and Berlin, C. (2014) 'Safety of the breast-feeding infant after maternal anesthesia', Paediatric Anaesthesia, 24(4), pp. 359-371. doi: 10.1111/pan.12331.

Desmawati, D. (2013) 'Penentu Kecepatan Pengeluaran Air Susu Ibu setelah Sectio Caesarea', Kesmas: National Public Health Journal, 7(8), p. 360. doi: 10.21109/kesmas.v7i8.22.

Farthing M, Salam MA, Lindberg G, Dite P, Khalif I, S.-L. E. (2013) 'Acute diarrhea in adults and children: A global perspective. World Gastroenterology Organisation Global Guidelines', J Clin Gastroenterol, 47(1), pp. 12-20.

Godhia, M. L. and Patel, N. (2013) 'Colostrum - Its composition, benefits as a nutraceutical: A review', Current Research in Nutrition and Food Science, 1(1), pp. 37-47. doi: 10.12944/CRNFSJ. 
1.1.04.

Hanieh, S. et al. (2015) 'Exclusive breast feeding in early infancy reduces the risk of inpatient admission for diarrhea and suspected pneumonia in rural Vietnam: A prospective cohort study Global health', BMC Public Health. BMC Public Health, 15(1), pp. 1-10. doi: 10.1186/s12889-015-2431-9.

Kaur, A. et al. (2016) 'The Effect of Exclusive Breastfeeding on Hospital Stay and Morbidity due to Various Diseases in Infants under 6 Months of Age: A Prospective Observational Study', International Journal of Pediatrics, 2016, pp. 1-6. doi: 10.1155/2016/7647054.

Kendall-Tackett, K., Cong, Z. and Hale, T. W. (2015) 'Birth Interventions Related to Lower Rates of Exclusive Breastfeeding and Increased Risk of Postpartum Depression in a Large Sample', Clinical Lactation, 6(3), pp. 8797. doi: 10.1891/2158-0782.6.3.87.

Kling, D. et al. (2016) 'Association between method of delivery and exclusive breastfeeding at hospital discharge', Journal of the American Osteopathic Association, 116(7), pp. 430-439. doi: 10.7556/jaoa.2016.087.

Mulyani, N. S. et al. (2018) 'Diarrhea among hospitalized children under five: A call for inclusion of rotavirus vaccine to the national immunization program in Indonesia', Vaccine.
Elsevier Ltd, 36(51), pp. 7826-7831. doi: 10.1016/j.vaccine.2018.05.031.

Quigley, M. A. et al. (2016) 'Exclusive breastfeeding duration and infant infection', European Journal of Clinical Nutrition. Nature Publishing Group, 70(12), pp. 1420-1427. doi: 10.1038/ ejcn.2016.135.

Sakalidis, V. S. et al. (2013) 'A comparison of early sucking dynamics during breastfeeding after cesarean section and vaginal birth', Breastfeeding Medicine, 8(1), pp. 79-85. doi: 10.1089/ bfm.2012.0018.

Suryati, T. (2013) '(Analisis Lanjut Data Riskesdas 2010) Persentase Operasi Caesaria Di Indonesia Melebihi Standard Maksimal, Apakah Sesuai Indikasi Medis?', Buletin Penelitian Sistem Kesehatan, 15(4 Okt), pp. 331338. doi: 10.22435/bpsk.v15i4Okt.3031.

UNICEF (2013) 'The Integrated Global Action Plan for Pneumonia and Diarrhoea (GAPPD)', p. 10.

Wulandari, D. R. and Dewanti, L. (2012) 'Rendahnya Praktik Menyusui pada Ibu Post Sectio Caesarea dan Dukungan Tenaga Kesehatan di Rumah Sakit The Low Practices of Breastfeeding for Sectio Caesarea Women and Health Workers Support in Hospital', Jurnal Kesehatan Masyarakat, 8, pp. 393-397. Available at:http://dx.doi.org/10.21109/ kesmas.v8i8.410. 